THURSDAY, MAY I8, I87I

\section{THE PEOPLE'S UNIVERSITY}

A GIGANTIC and imposing educational scheme is about to be launched, which, whether it proves feasible or not, must attract the attention and enlist the sympathy of all well-wishers to the intellectual development and material welfare of the country. This is noless an idea than the establishment of a National Working Men's University, which is to be founded with special reference to instruction in those subjects which have a direct bearing on the arts and manufactures. That our workmen are, as a rule, altogether ignorant of the scien. tific principles upon which the processes they ought to guide and govern are dependent, and that England in this respect stands in a much inferior position to continental nations, is now a well-recognised fact. The result of this lamentable ignorance is stated by certain authorities to be severely felt in those of our trades and manufactures in which we have to compete with other nations; and although this conclusion has been denied by many, yet concerning the necessity for scientific education amongst our artisans there has never been a difference of opinion. The question then arises, How are we to bring to our rising artisans on an extended and national scale the knowledge of scientific principles which they so much need, and for which the best of their class show so much desire and even aptitude? One solution to this problem is being attempted by the scheme of a National University for Industrial and Technical Training. The proposal is to establish a metropolitan institution in which complete and thorough instruction in all those branches of knowledge which are of importance to our manufacturing industry shall be given. It is proposed (I) to build ample lecturerooms, laboratories, art (as well as scientific) museums on the most extended scale ; (2) to create professorships both of the pure sciences and of such more technical subjects as can be systematically treated, and we will also hope chairs of at least such literary subjects as the modern languages; and (3) to found scholarships by which artisans may be enabled to live during the years of their studentship. This central university is to be connected with other similar institutions scattered over the country in the foci of the industrial pursuits, each carrying out in its locality the same function which the central one is to. perform perhaps on a somewhat higher scale for the metropolis and the country in'general.

The idea is a noble and grand one, but the difficulties of carrying it out are immense, whilst the dangers of the scheme proving abortive are scarcely less $\$ 0$. The first requisite in such a scheme for artisan education is money, the second condition of success is good management. If the wealthy city guilds come forward to the good work with subscriptions of tens and hundreds of thousands, and if men of ability and of high views and of sound practical knowledge on educational questions undertake to work the scheme, the University of the People may possibly become a reality.

That the best of the English artisans value a scientific training when it is placed within their reach, is a matter which has now been satisfactorily proved, and if any systern VOL. IV. of high science instruction can be inaugurated by which the force of thousands of powerful brains, now lying dormant, can be made productive, an increase of energy will be gained to the country of which we cannot form the slightest conception.

When, however, we come to count the cost, we may well doubt the accomplishment of the design, for we must set it down as a first principle that every artisan must not only be gratuitously taught, but also kept during the period of his studentship. This would necessitate a scholarship of at least 40 . per annum for each student; or $40,000 l$. for every thousand students; add to this a like sum (a moderate estimate) for the payment of professors, expenses of working the science departments, museums, \&c. we see that each student will cost probably nearly rool. There is, of course, plenty of money, even in the metropolis itself, which might with propriety be applied to this most laudable object, but whether such a sum can be raised as shall yield an annual income say of $80,000 l$. to $100,000 l$. large enough to support a People's University on a truly national scale (and anything less than this would be a practical failure) appears more than doubtful. For although the importance of this movement, in a national point of view, cannot in reality be overestimated, it is but too evident that this opinion is not held by the world at large, and certainly not (unless they are much belied) by rich corporations or city companies; and without aid from some such old and wealthy foundations, a scheme of this kind can scarcely be permanently supported.

The financial are, however, by no means the only or the most important difficulties which will beset the new University. These will only begin to be felt when the scheme has been started-such as dangers of giving an instruction too purely theoretic, or of running into the worse evil of teaching details without scientific aperçu.

In face of such difficulties it all the more behoves those who really believe the movement to be a wise and beneficial one, to exert themselves to support it. It is simply a duty to draw attention to a proposal which, if properly carried out, may improve to a very important extent the condition of Science in England.

\section{H. E. ROSCOE}

\section{THE SUN}

Le Soleil. Exposé des principales déconvertes modernes sur la structure de cet astre, son influnce datus l'univers et ses relations avec les autres corps celestes. Par le $\mathrm{P}$ A. Secchi, S.J. Pp. 422, 8vo. (Paris: Gauthier Villars, 1870. London: Williams and Norgate.)

The Sun: Ruler, Fire, Light, and Life of the Planetary System. By Richard A. Proctor, B.A., F.R.A S. Pp. 48o, crown 8vo. (London: Longmans, Green, and Co., 187r.)

D URING the past few years the number of workers in the domain of solar physics has been so great, their progress so rapid, and the results of their labours have been published in so many forms, that it has been difficult to keep pace with them. Under these circumstances, a summary of these labours, which shall extract what is most valuable from all, and refer the reader to the original publications for the remainder, is a great desideratum. 